\title{
Development of a bio-based adhesive from Protium heptaphyllum resin
}

\author{
Marcos Danilo Costa de Almeida1* (D), João Antonio Pessoa da Silva² (iD, \\ Felipe Fernando da Costa Tavares ${ }^{1}$ (D), Ludmila Leite Araujo ${ }^{1}$ (D), Jefferson de Souza Zeferino ${ }^{1}$ \\ and Ruth Marlene Campomanes Santana ${ }^{1}$
}

\author{
${ }^{1}$ Laboratório de Materiais Poliméricos - LAPOL, Departamento de Materiais, Escola de Engenharia, \\ Universidade Federal do Rio Grande do SuI - UFRGS, Porto Alegre, RS, Brasil \\ ${ }^{2}$ Laboratório de Tecnologia de Polímeros - LATEP, Departamento de Engenharia Química, \\ Universidade Federal do Rio Grande do Sul - UFRGS, Porto Alegre, RS, Brasil \\ *marcos.almeida@ueap.edu.br
}

\begin{abstract}
In this work, a bio-based adhesive is prepared from Protium heptaphyllum resin. The resin is first characterized by ${ }^{1} \mathrm{H}$ and ${ }^{13} \mathrm{C}$ nuclear magnetic resonance spectroscopy and the bioadhesive is then prepared using a simple mixture of the resin with linseed oil, catalyzed by cobalt octanoate, to induce crosslinking. The precursors and bioadhesive obtained are characterized by thermogravimetric analysis (TGA), differential scanning calorimetry (DSC) and Fourier transform infrared spectroscopy (FTIR). The NMR analysis shows the presence of groups of triterpenes, such as $\alpha$ - and $\beta$-amyrins, and diols, such as brein and maniladiol. Thermogravimetric analysis reveals that the resin has less thermal stability than the bioadhesive. Mechanical tests indicate that the bioadhesive has greater adhesion strength compared to the commercial adhesive, reaching an average stress at break of 7.66 and $0.113 \mathrm{MPa}$ for the wood and carbon steel substrates, respectively. In conclusion, the bioadhesive can be used for the production of composites.
\end{abstract}

Keywords: adhesive, Protium heptaphyllum, reticulation reaction, linseed oil.

How to cite: Almeida, M. D. C., Silva, J. A. P., Tavares, F. F. C., Araujo, L. L., Zeferino, J. S., \& Santana, R. M. C. (2021). Development of a bio-based adhesive from Protium heptaphyllum resin. Polimeros: Ciência e Tecnologia, 31(2), e2021014. https://doi.org/10.1590/0104-1428.10020

\section{Introduction}

Adhesives are polymeric materials capable of interacting, both chemically and physically, with a substrate in such a way that the stresses are transferred between both components ${ }^{[1]}$. Commercially available adhesives, such as polychloroprene, polyvinyl, cyanoacrylate and vinyl acetate, are generally produced from non-renewable sources. Furthermore, some of the most used petroleum-based adhesives contain dangerous chemicals, e.g., formaldehyde, which have a negative impact on the environment and human health ${ }^{[2]}$.

In order to produce more environmentally friendly materials, significant research has been focused on using renewable resources to obtain adhesives. The adhesives prepared from the modification of linseed oil ${ }^{[3]}$, soy $\operatorname{protein}^{[4,5]}$, castor oil plant ${ }^{[6,7]}$ lignin and chitosan ${ }^{[8-10]}$ are good examples of this approach. The employment of these raw materials is possible as a result of their active sites, such as hydroxyl groups and unsaturated bonds. These groups can react, in the presence of a catalyst, with crosslinking agents that have chemical groups compatible with the substrate (wood, metals or plastics).

Natural resins are extractive substances secreted by plants as a protective mechanism to injury. Most natural resins are composed of terpenes, which are macromolecules derived from isoprene (2-methyl-1,3-butadiene). These compounds present actives sites (double bonds and hydroxyl groups) that are prone to chemical attack and can be exploited for the development of adhesives.

In the Amazon region of Brazil, there are many species of trees that secrete natural resins with the potential for the development of adhesives. Among these natural resins, Protium heptaphyllum is highlighted for having an established market due to its application in the cosmetics industry. This resin is mostly composed of $\alpha$ - and $\beta$-terpenes ${ }^{[11]}$ and is used in folk medicine as an anti-inflammatory, analgesic, stimulant, cough remedy and for clearing airways ${ }^{[12]}$. Another important application of this resin is in the caulking of wooden boats, a classical craftwork realized by riverains.

The use of natural resins in their crude form for the preparation of adhesives results in poor mechanical resistance, due to their relatively small molecular weight and absence of interchain bonds. In this context, crosslinking with vegetable oils has been a strategy used for improving the mechanical performance of adhesives. Addis et al. ${ }^{[13]}$ performed a chemical modification of linseed oil from various crosslinking agents and tested it as an adhesive in three types of wood. They evaluated the curing time, the type of crosslinking agent 
and the rate of adhesive impregnation and reported that the material is a promising bioadhesive for wood.

Although Protium heptaphyllum resin has long been used by riverains for craftwork, its scientific investigation is very limited. Only the work of Vieira et al. ${ }^{[1]}$ reports the application of Protium heptaphyllum resin as an adhesive. The authors demonstrated that the pure resin can be used for the adhesion of wood; however, they verified that it has low mechanical resistance and becomes brittle after curing, which decreases its adhesion strength on the substrate surface.

In this work, a bioadhesive is prepared from the crosslinking of Protium heptaphyllum resin and linseed oil and catalyzed by cobalt octanoate $(12 \mathrm{Co})$. Linseed oil is selected because of its high content of double bonds, which is important for the formation of a consistent chemical network in the cured material. In addition, linseed oil acts as a plasticizer, which resolves the problem of brittleness described by Vieira et al..$^{[1]}$. The resin and bioadhesive are initially characterized and their chemical composition, thermal stability and main thermal transitions determined. Subsequently, the adhesion force of the bioadhesive is evaluated through shear stress assays in specimens of wood and carbon steel. A commercial adhesive from polychloroprene is used for comparison. On this basis, the aim of this study is to develop a bioadhesive suitable for the production of composites.

\section{Materials and Methods}

\subsection{Materials}

Protium heptaphyllum resin was acquired from a local market in Macapá, Brazil. The material was received as a dark gray solid, with some vegetable residues of branches and leaves dispersed among the solids. Linseed oil (Corfix, Porto Alegre) was acquired from a local market in Porto Alegre, Brazil, and received as a clear, crude and unpolymerized light yellow oil. The $12 \mathrm{Co} 12 \%$ catalyst was supplied by Miracema Nuodex (Guarulhos, Brazil). Chloroform P.A. 99.98\% and deuterated chloroform $\left(\mathrm{CDCl}_{3}\right)$ were purchased from Sigma Aldrich ${ }^{\circledR}$.

\subsection{Methods}

\subsubsection{Purification of Protium heptaphyllum resin}

The resin was first crushed with a hammer and vegetable residues (branches and leaves) were manually removed. The resin was then purified through solid/liquid Soxhlet extraction with chloroform at $70{ }^{\circ} \mathrm{C}$ for $8 \mathrm{~h}$. Finally, the extract was concentrated in an oven at $105^{\circ} \mathrm{C}$ for $24 \mathrm{~h}$, resulting in a red-orange translucent solid (Figure 1) with a mass yield of $92 \%$.

\subsubsection{Adhesive formulation and preparation of specimens for mechanical tests}

The bioadhesive was produced from the crosslinking of the Protium heptaphyllum resin and linseed oil in the presence of the $12 \mathrm{Co}$ catalyst. $12 \mathrm{Co}$ is considered the most efficient catalyst among transition metals and it can induce a crosslinking reaction of linseed oil at $82^{\circ} \mathrm{C}^{[14]}$. The bioadhesive preparation involved the simple mixing of the components at $100{ }^{\circ} \mathrm{C}$ in a mass ratio of $80: 20$ (resin/linseed) with $0.5 \%$ of $12 \mathrm{Co}$. In a typical procedure, $16 \mathrm{~g}$ of the purified Protium heptaphyllum resin were weighed in a porcelain crucible and heated to $100^{\circ} \mathrm{C}$ until complete liquefaction was achieved. Subsequently, linseed oil $(4 \mathrm{~g})$ and $0.5 \%$ of $12 \mathrm{Co}(0.01 \mathrm{~g})$ were added and the mixture was homogenized for $5 \mathrm{~min}$. This mixture was allowed to cure for $72 \mathrm{~h}$ in an oven at $60^{\circ} \mathrm{C}$. After curing, samples of the adhesive were collected for FTIR, TGA and DSC characterization.

\subsubsection{Characterization of precursor materials and bioadhesive}

${ }^{1} \mathrm{H}$ and ${ }^{13} \mathrm{C}$ nuclear magnetic resonance (NMR) spectroscopies were performed to identify the main compounds present in the purified Protium heptaphyllum resin. Samples were dissolved in deuterated chloroform at $60 \mathrm{mg} / \mathrm{mL}$ and analyzed at $50{ }^{\circ} \mathrm{C}$ using a Bruker ${ }^{\circledR}$ spectrometer, Avance III, $300 \mathrm{MHz}$.

The thermal stability of the purified resin, linseed oil and adhesive was evaluated using TGA. The analysis was performed using a TGA Q50 V20.13 Build 39 under a $\mathrm{N}_{2}$ flow rate of $100 \mathrm{~mL} / \mathrm{min}$ from room temperature to $840^{\circ} \mathrm{C}$ at a heating rate of $20^{\circ} \mathrm{C} / \mathrm{min}$. An alumina pan was used and the approximate sample mass was $15 \mathrm{mg}$.

DSC was performed on the purified resin, linseed oil and adhesive using a TA Instrument calorimeter with a $\mathrm{N}_{2}$ cooling module. Samples of $\sim 5 \mathrm{mg}$ were analyzed from 0 to $200^{\circ} \mathrm{C}$ at a heating rate of $10^{\circ} \mathrm{C} / \mathrm{min}$ and in a $\mathrm{N}_{2}$ flow rate of $50 \mathrm{~mL} / \mathrm{min}$.

FTIR spectroscopy was employed to evaluate the main functional groups of the Protium heptaphyllum resin and linseed oil. The spectra were collected with a Perkin-Elmer Frontier spectrometer in transmittance mode using the $\mathrm{KBr}$ pellet method in the range of $4000-650 \mathrm{~cm}^{-1}$. For the bioadhesive of Protium heptaphyllum, the analysis was

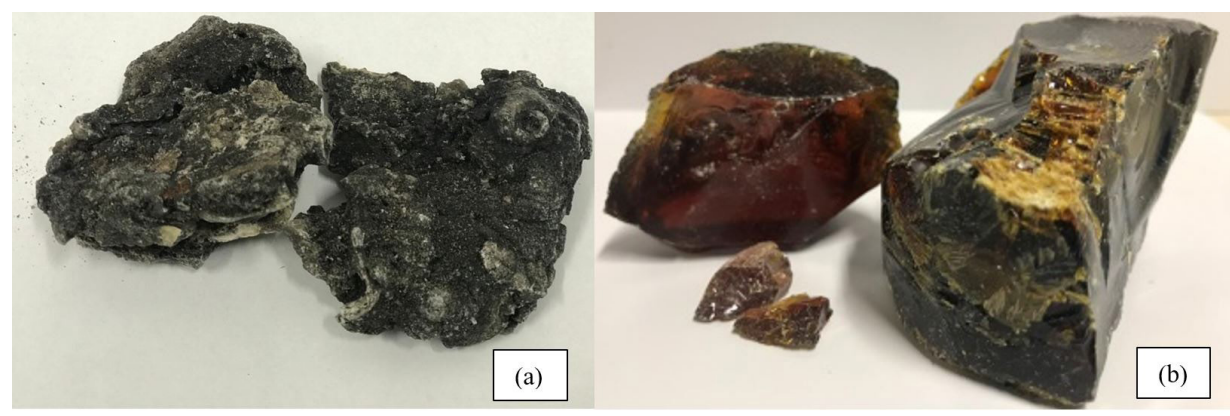

Figure 1. Protium heptaphyllum resin (a) before and (b) after purification. 
performed in total attenuated reflection using a wavenumber range from 4000 to $700 \mathrm{~cm}^{-1}, 16$ scans and a $4 \mathrm{~cm}^{-1}$ resolution.

\subsubsection{Mechanical shear testing}

To determine the adhesion force, the bioadhesive was prepared in a similar manner as described in section 2.2.2. The mixture (crude resin, linseed oil and catalyst) was impregnated in specimens of wood or carbon steel that were placed in an oven with air recirculation (DELEO, model ABAR-FC) at $60^{\circ} \mathrm{C}$ for $72 \mathrm{~h}$ for curing.

The carbon steel specimens were based on the ASTM D1002-10 ${ }^{[15]}$ standard, with dimensions of $100 \mathrm{~mm} \times 25 \mathrm{~mm}$ and thickness of $1.5 \mathrm{~mm}$. The bioadhesive was impregnated on the specimen with a grammage of $144 \mathrm{~g} / \mathrm{m}^{2}$, in a bonding area of $12.5 \times 25 \mathrm{~mm}^{2}$. After the contact of both specimen sides, they were attached with double metal clips.

For wooden specimens, the modified ASTM D906 $6^{[16]}$ standard was employed. Laminated eucalyptus wood with dimensions of $100 \mathrm{~mm} \times 25 \mathrm{~mm}$ and a thickness of $4 \mathrm{~mm}$ was used. The bioadhesive was applied on the substrate with a grammage of $154 \mathrm{~g} / \mathrm{m}^{2}$ in a bonding area of $30 \times 25 \mathrm{~mm}^{2}$. The specimens were again attached with double clips.

The tests were carried out using a universal machine EMIC, model 23-5D. The specimens were attached by two flat plate claw screws and tensioned. For the metal substrate, a shear rate of $1.27 \mathrm{~mm} / \mathrm{min}$ was used, according to ASTM D1002-10 ${ }^{[15]}$, while for the wooden specimens, a shear rate of $10 \mathrm{~mm} / \mathrm{min}$ was used, according to ASTM D906 ${ }^{[16]}$. The test with a commercial polychloroprene adhesive was made using the same procedure, except for the curing time, which was $72 \mathrm{~h}$.

Statistical analyzes were performed using the free PAST software, version 2.17c. Variance (ANOVA) and Tukey's test were used at the $95 \%$ significance level.

\subsubsection{Optical microscopy}

The micrographs of the fracture area in the specimens were observed using a digital optical microscope model U1000X with a magnification of $1000 \times$.

\section{Results and Discussions}

\subsection{Characterization of precursor materials and bioadhesive}

The ${ }^{1} \mathrm{H}$ and ${ }^{13} \mathrm{C} \mathrm{NMR}$ spectra of the Protium heptaphyllum resin are shown in Figures 2 and 3, respectively. Since techniques for separating the components of the Protium heptaphyllum resin were not used, the spectra are only discussed qualitatively, with the primary purpose of identifying functional groups and structures. For this, the chemical shifts of the compounds found in the Protium heptaphyllum resin depicted in the literature are used.

In the region between 0.8 and $2.0 \mathrm{ppm}$ for the ${ }^{1} \mathrm{H}$ NMR and 0 to $56 \mathrm{ppm}$ for the ${ }^{13} \mathrm{C}$ NMR spectra, a set of chemical shifts characteristic of carbon chains is noted; however, it is not possible to identify these compounds. In addition, no chemical deformations above 140 ppm were observed, which is typical of triterpenoids with alkene groups, such as $\beta$-amirinone, $\alpha$-amirinone and lupenone ${ }^{[17]}$. The peaks at $\beta-79.07 \mathrm{ppm}$ and $\alpha-77.03 \mathrm{ppm}$ in the ${ }^{13} \mathrm{C}$ NMR spectrum are related to carbons in position $\mathrm{C} 3$ linked to hydroxyls $(\mathrm{C}-\mathrm{OH})$, which is confirmed by the double doublet at 3.25 ppm in the ${ }^{1} \mathrm{H}$ NMR spectrum, which is characteristic of protons attached to carbons adjacent to hydroxyl groups. In addition, in the ${ }^{13} \mathrm{C}$ NMR spectrum, the peaks at $144.6 \mathrm{ppm}$ (C13) and $121.26 \mathrm{ppm}(\mathrm{C} 12)$ are characteristic of $\beta$-amyrin. The peaks at $139 \mathrm{ppm}(\mathrm{C} 13)$ and $124 \mathrm{ppm}(\mathrm{C} 12)$ are from $\alpha$-amyrin ${ }^{[17,18]}$. The peaks at $67.4 \mathrm{ppm}$ and $66.4 \mathrm{ppm}$ in the ${ }^{13} \mathrm{C}$ NMR spectrum are attributed to carbinolic carbons, at position $\mathrm{C} 16$, and the double doublet at $4.2 \mathrm{ppm}$ in the ${ }^{1} \mathrm{H}$ NMR spectrum is characteristic of diols, such as brein and maniladiol ${ }^{[17,19]}$.

The TGA curves and their respective derivatives (DTG) of the purified Protium heptaphyllum resin, linseed oil and bioadhesive are shown in Figure 4 . Table 1 presents the values of the thermal stability at $5 \%$ mass loss $\left(\mathrm{T}_{5 \%}\right)$, and the mass loss $\left(\Delta \mathrm{m}_{I}\right)$ and peak temperature $\left(\mathrm{T}_{\max }\right.$, which is the temperature of the maximum rate of decomposition obtained from the DTG curves) of each thermal event observed for the curves.

Figure 4 shows four thermal events for the resin and adhesive, while for the linseed oil, the degradation occurs in a single step. The first thermal event appears between 106 and $201{ }^{\circ} \mathrm{C}$ and is attributed to the loss of volatile components. It is noted that the resin $\left(\Delta \mathrm{m}_{1}=9.18 \%\right)$ presents a higher variation in mass loss than the adhesive $\left(\Delta \mathrm{m}_{1}=4.10 \%\right)$, which may be due to the thermal processes of heating at $100{ }^{\circ} \mathrm{C}$ until liquefaction and curing at $60{ }^{\circ} \mathrm{C}$ used for preparing the adhesive. The second thermal event is observed between 201 and $435^{\circ} \mathrm{C}$ and is related to the loss of the main components (amyrins and diols) of the Protium heptaphyllum resin, as reported by Silva Junior et al. ${ }^{[20]}$ and Vieira Junior et al. ${ }^{[17]}$. Silva Junior et al. ${ }^{[20]}$ showed that the isomers $\alpha$-and $\beta$-amyrins, the major components of Protium heptaphyllum resin are degraded in the range of 210 to $380{ }^{\circ} \mathrm{C}$. Vieira Junior et al. ${ }^{[17]}$ obtained similar results for the Protium heptaphyllum resin. In this step, the remaining mass of the resin $\left(\Delta \mathrm{m}_{2}=90.65 \%\right)$ is lost, while for the bioadhesive, a broadening of the peak $\left(\Delta \mathrm{m}_{2}=89.48 \%\right)$ is observed. From analyzing the $\mathrm{T}_{\max }$ of the both peaks, it is observed that the resin has the highest value; however, this does not mean that it has a greater thermal stability, since the peak broadening is displaced for a higher temperature

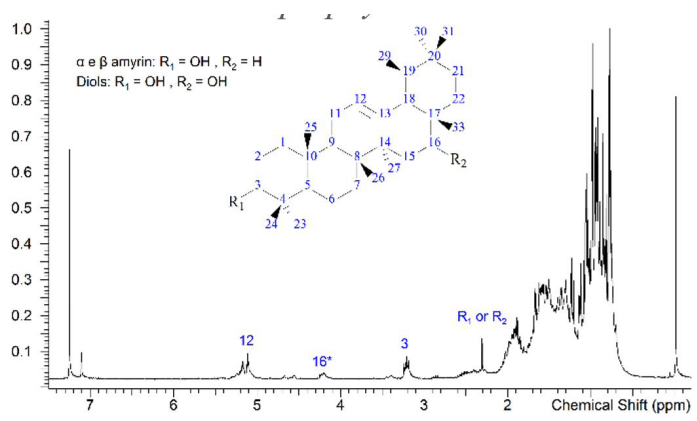

Figure 2. ${ }^{1} \mathrm{H}$ NMR spectrum of Protium heptaphylum resin. 


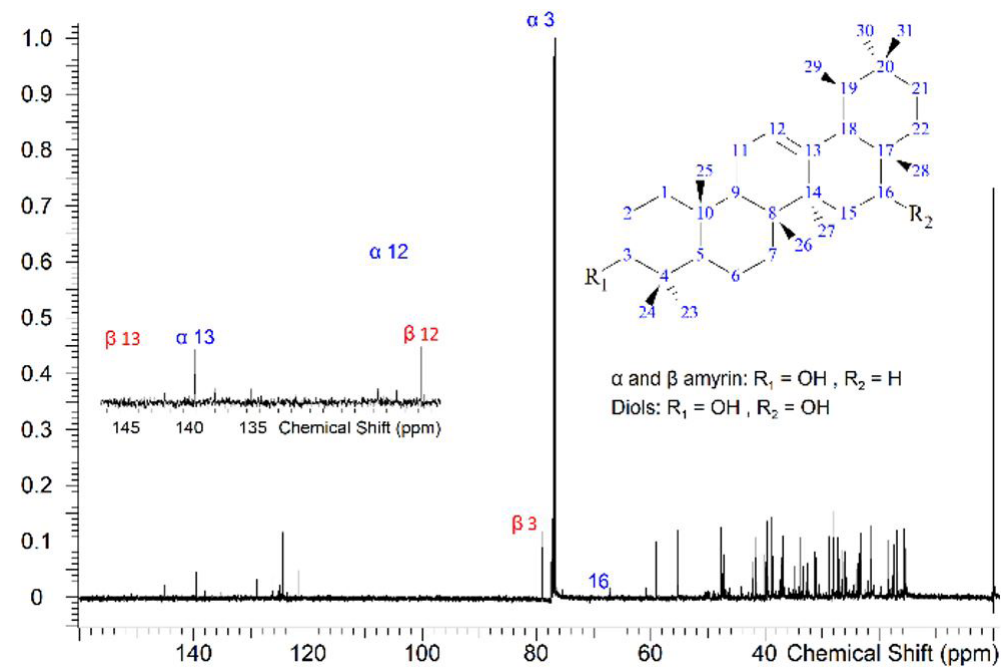

Figure 3. ${ }^{13} \mathrm{C}$ NMR spectrum of Protium heptaphyllum resin.
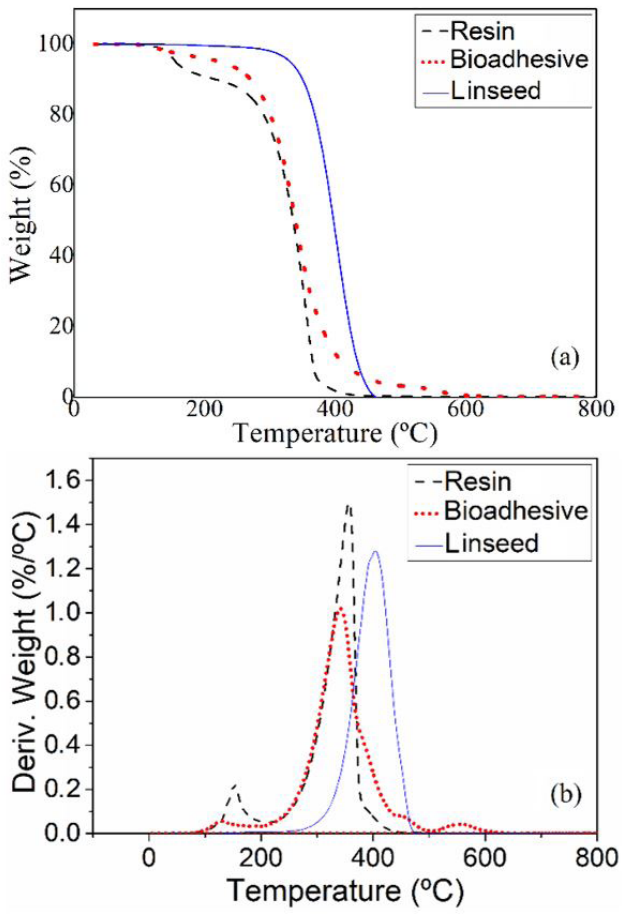

Figure 4. TGA (a) and DTG (b) curves for resin, adhesive and linseed oil.

and third and fourth additional peaks are identified for the bioadhesive.

The third (shoulder) and fourth thermal events were observed only for the bioadhesive. They occurred in the temperature range of 435 to $498{ }^{\circ} \mathrm{C}$ for the third peak $\left(\Delta \mathrm{m}_{2}=3.36 \%\right)$ and from 498 to $607^{\circ} \mathrm{C}$ for the fourth peak $\left(\Delta \mathrm{m}_{2}=2.84 \%\right)$. These peaks may be the decomposition from macromolecules or oligomers formed from the crosslinking of the Protium heptaphyllum resin with linseed oil, since they have $\mathrm{T}_{\max }$ higher than the crude resin and linseed oil.

The DSC results of the Protium heptaphyllum resin, linseed oil and bioadhesive are shown in Figure 5. Linseed oil showed an exothermic peak between 75 and $200{ }^{\circ} \mathrm{C}$, with a maximum close to $150^{\circ} \mathrm{C}$. Lazzari and Chiantore ${ }^{[21]}$ demonstrated that this exothermic peak, in the range of 100 to $200^{\circ} \mathrm{C}$, is a result of the formation of peroxides that react with conjugated double bonds characteristic of oils that have undergone some type of treatment or prepolymerization. Thus, it is inferred that the commercial linseed oil used to prepare the bioadhesive had already been oxidized to some level, probably due to exposure to the environment. The oxidation of triglycerides, using transition metals, such as cobalt, as catalysts, occurs from the hydrogen abstraction of methylene groups present in the unsaturation. The cobalt catalyst provides both the formation of hydroperoxides and their decomposition due to the formation of stable ions. The combination of these radicals initiates the crosslinking reaction ${ }^{[22]}$. Other possible termination reactions described by Charamzová et al ${ }^{\left[{ }^{23]}\right.}$ suggest that alkoxide groups, formed from hydroxyl groups (major components of Protium heptaphyllum resin), can be combined with radicals from unsaturations.

The resin presented two endothermic events, compatible with the results reported by Vieira Junior et al.$^{[17]}$ for Protium heptaphyllum resin. The first one appears close to $52{ }^{\circ} \mathrm{C}$, with an enthalpy of $3.3 \mathrm{~J} / \mathrm{g}$, and is associated with the softening of the material. The second one arises in the range of 100 to $160^{\circ} \mathrm{C}$ and is more intense, with an enthalpy of $24.89 \mathrm{~J} / \mathrm{g}$. This is attributed to the loss of volatile materials, such as water or solvent, which are likely to be residues from the purification process. For the adhesive, the DSC curve exhibited two exothermic events, with the first one occurring in the range of 63 to $126^{\circ} \mathrm{C}$, with an enthalpy of $15.32 \mathrm{~J} / \mathrm{g}$, and the second one in the range of 126 to $190{ }^{\circ} \mathrm{C}$ with an enthalpy of $7.50 \mathrm{~J} / \mathrm{g}$. Both events may indicate a two-step curing of the adhesive, in which in the first step occurs via the oxidation of the linseed oil or reactions of $\mathrm{OH}$ groups from resin with unsaturated groups of linseed oil, while the second step occurs with crosslinking between the linseed 
Table 1. Main thermal events in the samples.

\begin{tabular}{|c|c|c|c|c|c|c|c|c|c|c|}
\hline \multirow{4}{*}{ Samples } & \multirow{4}{*}{$\frac{\mathbf{T}_{5 \%}}{\left({ }^{\circ} \mathrm{C}\right)}$} & \multicolumn{8}{|c|}{ Thermal events } & \multirow{4}{*}{$\begin{array}{c}\text { Ash } \\
(\%)\end{array}$} \\
\hline & & \multicolumn{2}{|c|}{$1^{0}$} & \multicolumn{2}{|c|}{$2^{\circ}$} & \multicolumn{2}{|c|}{$3^{\circ}$} & \multicolumn{2}{|c|}{$4^{\circ}$} & \\
\hline & & $\Delta m$ & $\mathbf{T}_{\max }$ & $\Delta m$ & $\mathbf{T}_{\max }$ & $\Delta m$ & $\mathbf{T}_{\max }$ & $\Delta m$ & $\mathbf{T}_{\text {max }}$ & \\
\hline & & wt.\% & $\left({ }^{\circ} \mathrm{C}\right)$ & wt. $\%$ & $\left({ }^{\circ} \mathrm{C}\right)$ & wt.\% & $\left({ }^{\circ} \mathrm{C}\right)$ & wt.\% & $\left({ }^{\circ} \mathrm{C}\right)$ & \\
\hline Resin & 155 & 9.28 & 152 & 90.65 & 357 & - & - & - & - & 0.07 \\
\hline Linseed & 331 & 100 & 404 & - & - & - & - & - & - & 0.00 \\
\hline Bioadhesive & 222 & 4.10 & 129 & 89.48 & 341 & 3.36 & 457 & 2.84 & 556 & 0.22 \\
\hline
\end{tabular}

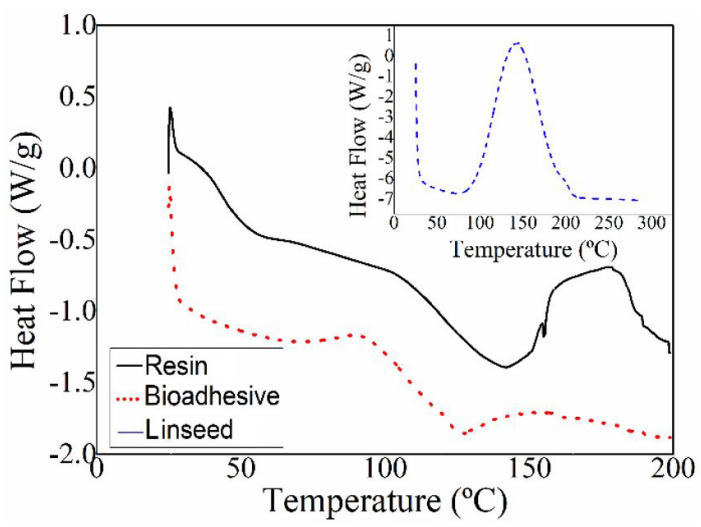

Figure 5. DSC curves for samples of Protium heptaphyllum resin, linseed oil and bioadhesive.

oil chains or between the linseed oil and components of the Protium heptaphyllum resin (amyrins and diols).

To assess whether the exothermic event observed for the bioadhesive in Figure 5 is from curing, thermograms from DSC were evaluated at 0,24 and $48 \mathrm{~h}$ of curing. The results are exhibited in Figure 6. In general, the curves also showed two exothermic events and an evolution in the energy released was observed. The first event $\left(70\right.$ to $\left.125^{\circ} \mathrm{C}\right)$ released $5.22 \mathrm{~J} / \mathrm{g}$ at $0 \mathrm{~h}$ and $8.60 \mathrm{~J} / \mathrm{g}$ at $48 \mathrm{~h}$. Similarly, the second exothermic event $\left(125\right.$ to $\left.190^{\circ} \mathrm{C}\right)$ increased from $4.80 \mathrm{~J} / \mathrm{g}$ at $0 \mathrm{~h}$ to $8.61 \mathrm{~J} / \mathrm{g}$ at $48 \mathrm{~h}$. Thus, the fact that this energy increases with the elapsed curing time of the bioadhesive is an indication that chemical bonds are formed (crosslinking), since this behavior is characteristic of a curing process.

From comparing the resin and bioadhesive spectra, Figure 7, the main difference is the decrease in the intensity of the bands at 3430 and $3100 \mathrm{~cm}^{-1}$, corresponding to the $\mathrm{OH}$ groups of the resin components (amyrins, brein and maniladiol) and the $=\mathrm{C}-\mathrm{H}$ groups of the linseed oil, respectively. The reduction of the $\mathrm{OH}$ band is possibly a consequence of the reaction of $\mathrm{OH}$ with double bonds through an oxidation mechanism ${ }^{[23]}$. The $=\mathrm{C}-\mathrm{H}$ band is indicative of the crosslinking of the resin with linseed oil, since the bioadhesive does not show this band. Such processes can be correlated with the DSC results, in which a double-step curing was observed.

\subsection{Adhesion strength in wood and steel}

The adhesion strength of the bioadhesive was evaluated through shear stress assays in carbon steel and wood substrates. In addition, a commercial adhesive (polychloroprene) was used

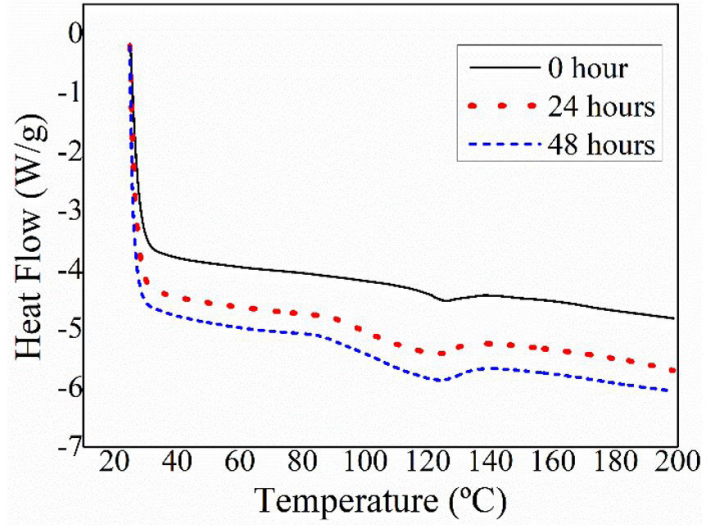

Figure 6. DSC curves for bioadhesive samples at 0, 24 and $48 \mathrm{~h}$.

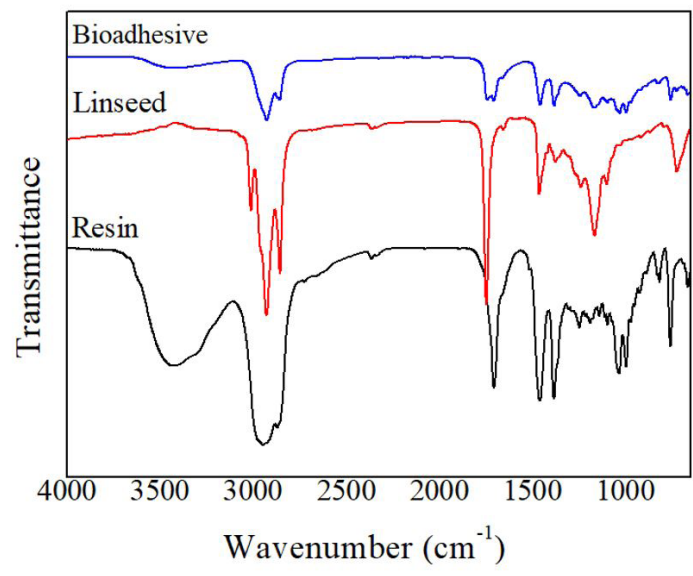

Figure 7. FTIR spectra for resin, adhesive and linseed oil.

for reference. Figure 8 shows the results of the mechanical shear stress tests and Table 2 the ANOVA of the values obtained. Comparing the bioadhesive and polychloroprene, it is observed that the adhesion strength of the first one is 3 times the second one for the wooden substrate, and 2 times for the metallic substrate. In terms of performance between substrates, the difference was significantly higher, being the shear stress of the wooden substrate 67 times of the metallic substrate for the bioadhesive, and 47 times for the polychloroprene.This result is related to the greater affinity of the resin with the wood material, which has surface groups that facilitate physical interactions and a roughness that favors mechanical anchoring. Besides, the penetration of the 
Table 2. ANOVA results for substrates.

\begin{tabular}{ccccccc}
\hline Substrate & Factor & $\begin{array}{c}\text { Sum of } \\
\text { squares }\end{array}$ & DF & $\begin{array}{c}\text { Mean } \\
\text { square }\end{array}$ & F & P-valor \\
\hline Metal & $\begin{array}{c}\text { Between } \\
\text { groups }\end{array}$ & 13018 & 1 & 13 & 14.89 & $\mathbf{0 . 0 0 2 7 2}$ \\
& $\begin{array}{c}\text { Within } \\
\text { groups }\end{array}$ & 10489 & 12 & & & \\
Wood & $\begin{array}{c}\text { Between } \\
\text { groups }\end{array}$ & 85.6104 & 1 & 85.6104 & 109.4 & $\mathbf{4 . 7 0 2 . 1 0} \mathbf{7 0}^{-7}$ \\
& $\begin{array}{c}\text { Within } \\
\text { groups }\end{array}$ & 8.60465 & 11 & 0.78224 & & \\
\hline
\end{tabular}

$\mathrm{DF}=$ degrees of freedom; $\mathrm{F}=$ value from the $\mathrm{F}$ distribution; $\mathrm{P}$-valor $=$ probability of significance.

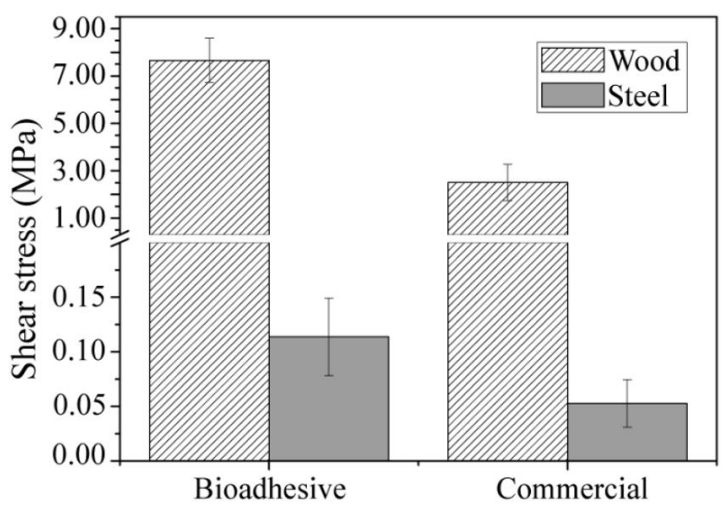

Figure 8. Comparative results of shear stress of samples evaluated on steel and wood substrates. adhesive into the pores of the substrate (absorption effect) provides greater resistance, and this effect appears for the wood but is absent for the metallic substrate ${ }^{[24]}$. The values of tensile shear stress are much higher than those obtained by Vieira et al. ${ }^{[1]}$, who employed crude Protium heptaphyllum resin as an adhesive and reached only $0.14 \mathrm{MPa}$ of shear stress using wood as a substrate. This better performance is mainly attributed to the crosslinking with linseed oil. In addition, the linseed oil acts as an internal lubricant, providing gains in deformation and eliminating the problem of brittleness reported by Vieira et al. ${ }^{[11]}$. Compared with the polychloroprene adhesive, the bioadhesive of Protium heptaphyllum was superior, as evidenced by the higher average values of shear stress for both substrates that were statistically different $(\mathrm{p}<0.05)$ according to ANOVA (Table 2). The difference in performance was more visible for the wood substrate, since the bioadhesive was three times higher than the polychloroprene.

Figure 9 shows micrographs of the fractured area of samples from adhesion strength tests for both substrates. According to Wei et al. ${ }^{[25]}$, there are three different failures that can occur in adhesives: adhesive failure, cohesive failure and mixing failure. In this work, different failures were observed in the tested substrates. For the metallic substrate, there were areas where the adhesive completely detached from the substrate (delimited area), characterizing adhesive failure and parts where the contact area still had adhesive, showing a cohesive fracture. The mechanical interlocking, adsorption, and chemical bonding are the three primary mechanisms that control the adhesion ${ }^{[26]}$. Besides, the roughness of the metallic surface is another decisive factor for the interaction ${ }^{[27]}$. Therefore, one reason that may have contributed to the adhesive having presented
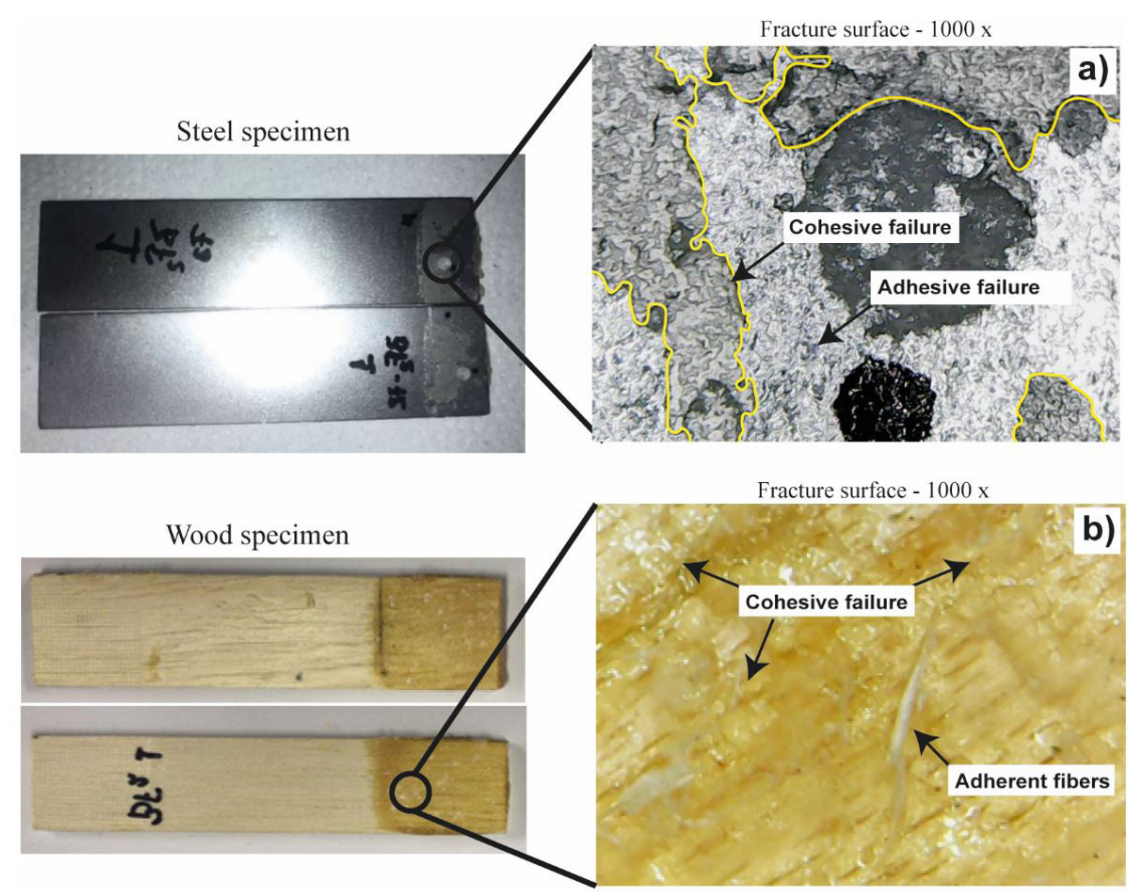

Figure 9. Micrography of the fractured surface area of the adhesion strength specimen tests of the Protium heptaphyllum adhesive, realized in carbon steel (a) and wood as substrates (b). 
adhesive failure is the fact that the substrate has undergone no kind of pre-treatment to increase adhesion. For the wood adherent, cohesive failure is perceived in regions of the bonding area with part of the adherent fibers (Figure 9b), which for ASTM D5573-99 ${ }^{[28]}$ standard can be defined as Light-Fiber-Tear failure (LFT failure). In both cases, the occurrence of cohesion failures may be related to a slight reticulation of the bioadhesive ${ }^{[29]}$, which did not form a consistent interlacing among the molecules that are required to hinder an early cohesion fracture during the shearing of the bioadhesive. On the other hand, it indicates that the Protium heptaphyllum adhesive has a fixation to the substrate stronger than the internal resistance (cohesion), which is required for adherence behavior ${ }^{[25]}$.

\section{Conclusions}

A bioadhesive was prepared from the crosslinking of Protium heptaphyllum resin with linseed oil using cobalt octanoate as a catalyst.

Through ${ }^{1} \mathrm{H}$ and ${ }^{13} \mathrm{C}$ NMR spectroscopy analyzes it was confirmed the main chemical structures of the Protium heptaphyllum resin. From the thermal analyzes it was identified a curing procress, which was additionally noted in the FTIR spectra. The mechanical assays results demonstrated that the bioadhesive prepared has greater mechanical properties than the commercial material (polychloroprene) used as reference. It is highlighted that the adhesion strength of the bioadhesive was three times that of the commercial adhesive used as reference for the wood substrate.

Finally, taking in to account the good results obtained for the wood substrate, we consider that the bioadhesive prepared from the Protium heptaphyllum adhesive has potential to be applied in the production of wood-based composites.

\section{Acknowledgements}

The authors would like to thank the technicians, scholarship and professors responsible for the Polymeric Materials Laboratory-LAPOL of the Federal University of Rio Grande do Sul of PPGE3M.

\section{References}

1. Conner, A. H., \& Bhuyan, M. S. H. (2017). Wood: adhesives. Reference Module in Materials Science and Materials Engineering, 1-17. https://doi.org/10.1016/b978-0-12-803581-8.01932-9.

2. Norström, E., Fogelström, L., Nordqvist, P., Khabbaz, F., \& Malmström, E. (2015). Xylan - a green binder for wood adhesives. European Polymer Journal, 67, 483-493. http:// dx.doi.org/10.1016/j.eurpolymj.2015.02.021.

3. Sahoo, S. K., Khandelwal, V., \& Manik, G. (2019). Synthesis and characterization of low viscous and highly acrylated epoxidized methyl ester based green adhesives derived from linseed oil. International Journal of Adhesion and Adhesives, 89, 174-177. http://dx.doi.org/10.1016/j.ijadhadh.2019.01.007.

4. Mo, J., Wang, F., Xu, Z., Feng, C., Fang, Y., Tang, X., \& Shen, $X$. (2019). Characterization and performance of soybean protein modified by tyrosinase. International Journal of Adhesion and Adhesives, 92, 111-118. http://dx.doi.org/10.1016/j. ijadhadh.2019.04.013.
5. Pang, H., Zhao, S., Wang, Z., Zhang, W., Zhang, S., \& Li, J. (2020). Development of soy protein-based adhesive with high water resistance and bonding strength by waterborne epoxy crosslinking strategy. International Journal of Adhesion and Adhesives, 100, 102600. http://dx.doi.org/10.1016/j. ijadhadh.2020.102600.

6. Moghadam, P. N., Yarmohamadi, M., Hasanzadeh, M., \& Nuri, S. (2016). Preparation of polyurethane wood adhesives by polyols formulated with polyester polyols based on castor oil. International Journal of Adhesion and Adhesives, 68, 273282. http://dx.doi.org/10.1016/j.ijadhadh.2016.04.004.

7. Oliveira, P. R., May, M., Panzera, T. H., Scarpa, F., \& Hiermaier, S. (2020). Reinforced biobased adhesive for eco-friendly sandwich panels. International Journal of Adhesion and Adhesives, 98 , 102550. http://dx.doi.org/10.1016/j.ijadhadh.2020.102550.

8. Ji, X., Li, B., Yuan, B., \& Guo, M. (2017). Preparation and characterizations of a chitosan-based medium-density fiberboard adhesive with high bonding strength and water resistance. Carbohydrate Polymers, 176, 273-280. http:// dx.doi.org/10.1016/j.carbpol.2017.08.100. PMid:28927608.

9. Ji, X., \& Guo, M. (2018). Preparation and properties of a chitosan-lignin wood adhesive. International Journal of Adhesion and Adhesives, 82, 8-13. http://dx.doi.org/10.1016/j. ijadhadh.2017.12.005.

10. Vargas Villanueva, J. G., Sarmiento Huertas, P. A., Galan, F. S., Esteban Rueda, R. J., Briceño Triana, J. C., \& Casas Rodriguez, J. P. (2019). Bio-adhesion evaluation of a chitosan-based bone bio-adhesive. International Journal of Adhesion and Adhesives, 92, 80-88. http://dx.doi.org/10.1016/j.ijadhadh.2019.04.009.

11. Vieira, R. K., Vieira, A. K., Kim, J. T., \& Netravali, A. N. (2014). Characterization of Amazonic White Pitch (Protium heptaphyllum) for potential use as 'green' adhesive. Journal of Adhesion Science and Technology, 28(10), 963-974. http:// dx.doi.org/10.1080/01694243.2014.880220.

12. Bandeira, P. N., Deusdênia, O., Pessoa, L., Teresa, M., Trevisan, S., \& Gomes, L. (2002). Secondary metabolites of Protium heptaphyllum march. Quimica Nova, 25(6b), 1078-1080. http:// dx.doi.org/10.1590/S0100-40422002000700006.

13. Addis, C. C., Koh, R. S., \& Gordon, M. B. (2020). Preparation and characterization of a bio-based polymeric wood adhesive derived from linseed oil. International Journal of Adhesion and Adhesives, 102, 102655. http://dx.doi.org/10.1016/j. ijadhadh.2020.102655.

14. Juita, Dlugogorski, B. Z., Kennedy, E. M., \& Mackie, J. C. (2011). Oxidation reactions and spontaneous ignition of linseed oil. Proceedings of the Combustion Institute, 33(2), 2625-2632. http://dx.doi.org/10.1016/j.proci.2010.06.096.

15. American Society for Testing and Materials (2019). ASTM D 1002-10: Standard Test Method for Apparent Shear Strength of Single-Lap-Joint Adhesively Bonded Metal Specimens by Tension Loading (Metal-To-Metal). West Conshohocken: ASTM.

16. American Society for Testing and Materials (2017). ASTM D 906: Standard Test Method for Strength Properties of Adhesives in Plywood Type Construction in Shear by Tension Loading. West Conshohocken: ASTM.

17. Vieira, G. M., Jr., Souza, C. M., \& Chaves, M. H. (2005). The Protium heptaphyllum resin: isolation, structural characterization and evaluation of thermal properties. Quimica Nova, 28(2), 183-187. http://dx.doi.org/10.1590/S0100-40422005000200003.

18. Vásquez, L. H., Palazon, J., \& Navarro-Ocaña, A. (2012). The pentacyclic triterpenes e $\alpha, \beta$-amyrins: a review of sources and biological activities. In: L. H. Vázquez (Ed.), Phytochemicals: a global perspective of their role in nutrition and health (pp. 487-502). United States: IntechOpen. 
19. Maia, J. G., \& Zoghbi, M. G. B. (1998). Óleos essenciais da Amazônia: inventário da flora aromática. In: L. G. J. Farias \& C. M. L. Costa. Tópicos especiais de produtos naturais (pp. 147-162). Brasil: POEMA.

20. da Silva Júnior, W. F., Pinheiro, J. G. O., Moreira, C. D. L. F. A., Rüdiger, A. L., Barbosa, E. G., Lima, E. S., da Veiga Júnior, V. F., da Silva Júnior, A. A., Aragão, C. F. S., \& de Lima, Á. A. N. (2017). Thermal behavior and thermal degradation kinetic parameters of triterpene $\mathrm{a}, \mathrm{b}$ amyrin. Journal of Thermal Analysis and Calorimetry, 127(2), 1757-1766. http://dx.doi. org/10.1007/s10973-016-6046-x.

21. Lazzari, M., \& Chiantore, O. (1999). Drying and oxidative degradation of linseed oil. Polymer Degradation \& Stability, 65(2), 303-313. http://dx.doi.org/10.1016/S0141-3910(99)000208.

22. Lima, G. E. S., Nunes, E. V., Dantas, R. C., Simone, C. A., Meneghetti, M. R., \& Meneghetti, S. M. P. (2018). Catalytic behaviors of coiI and MnII compounds bearing $\alpha$-Diimine ligands for oxidative polymerization or drying oils. Journal of the Brazilian Chemical Society, 29(2), 412-418. http://dx.doi. org/10.21577/0103-5053.20170155.

23. Charamzová, I., Vinklárek, J., Kalenda, P., \& Honzícek, J. (2018). Application of oxovanadium complex stabilized by $\mathrm{N}, \mathrm{N}, \mathrm{N}, \mathrm{N}$-chelating ligand in air-drying paints. Coatings, $8(6)$, 204. http://dx.doi.org/10.3390/coatings8060204.

24. Gardner, D. J., Blumentritt, M., Wang, L., \& Yildirim, N. (2015). Adhesion theories in wood adhesive bonding. In K.
L. Mittal (Ed.), Progress in adhesion and adhesives (pp. 125-168). United States: Scrivener Publishing. http://dx.doi. org/10.1002/9781119162346.ch5.

25. Wei, H., Xia, J., Zhou, W., Zhou, L., Hussain, G., Li, Q., \& Ostrikov, K. (2020). Adhesion and cohesion of epoxy-based industrial composite coatings. Composites. Part B, Engineering, 193, 108035. http://dx.doi.org/10.1016/j.compositesb.2020.108035.

26. Baldan, A. (2012). Adhesion phenomena in bonded joints. International Journal of Adhesion and Adhesives, 38, 95-116. http://dx.doi.org/10.1016/j.ijadhadh.2012.04.007.

27. Chen, P., Wang, Y., Li, J., Wang, H., \& Zhang, L. (2018). Adhesion and erosion properties of epoxy resin composite coatings reinforced with fly ash cenospheres and short glass fibers. Progress in Organic Coatings, 125, 489-499. http:// dx.doi.org/10.1016/j.porgcoat.2018.09.029.

28. American Society for Testing and Materials - ASTM. (2019) ASTM D5573-99: standard practice for classifying failure modes in fiber-reinforced-plastic (FPR). West Conshohocken: ASTM.

29. Silva, L. F. M., Ochsner, A., \& Adams, R. D. (2011). Handbook of adhesion technology. Berlin: Springer. http://dx.doi. org/10.1007/978-3-642-01169-6.

Received: Dec. 21, 2020

Revised: Apr. 24, 2021

Accepted: May 17, 2021 